\title{
Germany's tight budget
}

Munich. Germany's belt-tightening 1994 budget, announced last week, precludes overall growth in science. But the prospects could have been a lot worse.

The research ministry's share of the federal budget for 1994 will be restricted to around DM9.5 billion (US\$5.9 billion), the same as in the current year. But research organizations are relieved that the 'fivetimes-five' agreements, which promised five per cent annual growth from 1991 to 1995 , will not be broken. And there will be no back-pedalling on promises to maintain the high level of support to the new Länder.

Research minister Paul Krüger, an east German in office for only three months, has had the task of sharing out a budget with zero increase while inflation is running at 4.5 per cent. The ministry has already committed itself in principle to bolstering research in new technology and building up the research infrastructure in eastern Germany; Krüger says this can now be achieved only by making research 'more efficient'. Although 'efficiency' tends to be a euphemism for 'cuts', in this case the distribution of the reduced budget will probably be welcomed by all except those whose work is directly affected by shifts in priority.

The areas hit include conventional energy research and flight and marine technology. But the budget also raises the prospect of reduced future contributions to international enterprises such as the European Space Agency (ESA), which receives 23.6 per cent of its budget (this year DM 1.2 billion) from Germany. The federal government says it

plans to open negotiations with its partners, acknowledging that such steps will require the cooperation of all ESA member states.

But not all is gloom. Krüger says that biotechnology and transport technology, for example, will receive more support ( 2.3 and 4.0 per cent respectively), as will health research (3.3 per cent), ecology (2.2 per cent) and climate research ( 1.8 per cent $)$. All figures are, however, below inflation. Information technology remains a high priority, but Krüger is letting the European Communities shoulder that burden, and hopes to reduce the ministry's contribution in that area. Similarly, there are no extra funds for environmental research, where Krüger wants research institutes to take responsibility.

The major pure and applied research organizations outside the universities, the Max Planck Society and the Fraunhofer Society, will be given their promised five per cent increases, but - as also promised - the national research centres will have no increase over 1993. These large-scale centres, widely regarded as particularly inefficient and inflexible, have been under pressure for the past few years.

But eastern Germany is the clearest winner, if such a term can be applied to the underprivileged new Länder. True to his word, Krüger is allocating an extra DM 100 million (US\$62.5 million), an increase of 13.7 per cent, to support research and its infrastructure in the region. Part of this money will be given to "promote cooperation between university research and industry". Although generally fashionable in Europe,

\section{Hasty exit from APS}

Washington. Mystery this week surrounds the departure of Richard Werthamer, erstwhile executive secretary of the American Physical Society (APS), who was suddenly
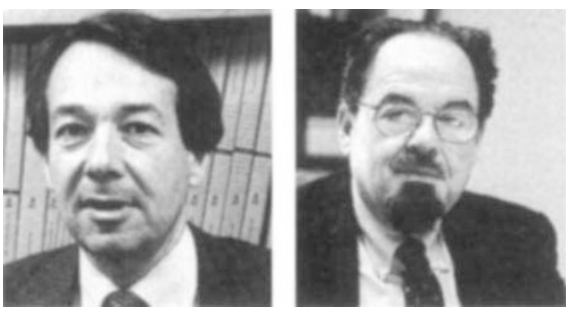

Richard Werthamer (left) and Harry Lustig

and unexpectedly ousted last week from the main administrative job at the 43,000 -strong professional grouping.

Several of APS's élite band of general councillors said last week that they were unaware of Werthamer's departure, as indeed was Werthamer himself. It was "a rumour I'm not aware of', he said on
Wednesday last week. But by Friday he had left the Manhattan headquarters of APS, which issued a bland statement citing "differences concerning APS management policy and practices" as an explanation for his "resignation".

Members of the APS council which removed Werthamer, including president-elect Burton Richter of the Stanford Linear Accelerator Center in California, referred enquiries to the president, Don Langenberg of the University of Maryland. But Langenberg was not returning calls.

Werthamer, who joined APS in 1991 from a medical instrument company, was engaged in the delicate process of moving APS's large publishing staff from New York state to new premises on Langenberg's Maryland campus, a move still due to take place in October. He will be replaced temporarily by long-time treasurer Harry Lustig, while a panel under past-president Ernest Henley searches for a new executive secretary. this concept may not be easily implemented in an environment where research is still not properly reintegrated into universities.

The Deutsche Forschungsgemeinschaft (DFG), which sponsors research in universities, also benefits from the five-times-five agreement, to which its sponsor, the education ministry, has adhered. But education, with a four per cent reduction from this year's budget, has fared even worse than research. The sharpest reduction will be in the budget of the body responsible for student grants, which will be reduced from DM2.55 billion for undergraduate support this year to DM2.3 billion next year; parents will be expected to bridge the gap. And despite chronic overcrowding, there is no increase in the university building fund.

Alison Abbott

\section{New NSF director nominated}

Washington. President Bill Clinton has nominated Neal Lane, an atomic physicist and provost of Rice University, Texas, as director of the National Science Foundation (NSF). If his nomination is confirmed, Lane, who is 54 , says his main chal-

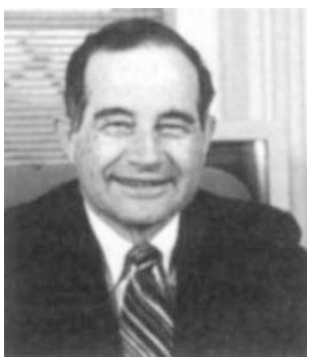

Neal Lane, facing the "squeeze" lenge at the $\$ 3$ billion agency will be "to set priorities that will promote progress in science and engineering".

A member of the Democratic Party whose wife, Joni Sue, is active in party politics, Lane says: "I know the administration is strongly committed to research and education, so I had no reservations about accepting".

A native of Oklahoma and a long-time physics lecturer at Rice, Lane briefly worked for the NSF as director of the physics division in 1980. He has also spent some time at Queen's University, Belfast, and at the Joint Institute for Laboratory Astrophysics in Boulder, Colorado, and was chancellor of the University of Colorado during two financially difficult years from 1984 .

Lane says he acknowledges that many researchers "do fear being squeezed" as research becomes more expensive. President Clinton has requested a 16 per cent increase in NSF for the coming financial year, although Congress is unlikely to appropriate all of it.

If confirmed, one of Lane's first tasks will be to help to decide the outcome of a review of NSF's large supercomputer centres, which were set up in 1985 on the recommendation of a panel that he chaired

Colin Macilwain 